\title{
STABILOMETRIC ASSESSMENT: IMPLICATIONS FOR THE PRESCRIPTION OF MEDICAL DEVICES
}

\section{EVALUAREA STABILOMETRICĂ: IMPLICATII ÎN PRESCRIEREA DISPOZITIVELOR MEDICALE}

\author{
Gabriel STAN ${ }^{1 *}$, Daniel PETCU ${ }^{2}$, Gheorghe BERIJAN ${ }^{2}$ \\ ${ }^{1}$ Elias Emergency University Hospital, Department of Orthopedics-Traumatology, 17 Marasti Blvd., Bucharest, email: gabisus2000@yahoo.com \\ ${ }^{2}$ National Research and Development Institute for Textiles and Leather - Division: Leather and Footwear Research Institute, 93 Ion Minulescu \\ St., Bucharest, Romania, email: icpi@icpi.ro
}

STABILOMETRIC ASSESSMENT: IMPLICATIONS FOR THE PRESCRIPTION OF MEDICAL DEVICES

ABSTRACT. The medical literature defines posture by positioning and orientation of body segments relative to the direction of the gravitational field. Balance encompasses all static and dynamic actions performed by the body as a result of the interaction between postural control mechanisms in order to avoid falling. Maintaining a normal posture is a prerequisite for minimizing internal stress manifested in tissues. Stabilometry studies evolution, under static conditions, of the center of pressure, defined as the origin of the reaction force vector in relation to the support surface. The aging process or diseases such as diabetes, rheumatoid arthritis or pathomechanics, affecting posture by increasing instability and the risk of falls. There is medical evidence that demonstrates the positive effect of medical devices (orthopedic shoes or orthoses) on posture. An important role in prescribing and assessing the influence of medical devices on posture is that of stabilometry, namely assessing posture under static conditions. The article proposes to assess the main stabilometric parameters determined using AccuGait-AMTI force platform and to correlate them with technical characteristics of medical devices.

KEY WORDS: stabilometry, posture, medical device

EVALUAREA STABILOMETRICĂ: IMPLICATII ÎN PRESCRIEREA DISPOZITIVELOR MEDICALE

REZUMAT. Literatura medicală defineşte postura prin poziţionarea şi orientarea segmentelor corporale în raport cu direcţia câmpului gravitaţional. Echilibrul reprezintă totalitatea acţiunilor statice şi dinamice efectuate de corp ca urmare a interacţiunii dintre mecanismele de control postural, cu scopul evitării căderii. Menţinerea unei posturi normale este o condiţie esenţială pentru reducerea la minimum a tensiunilor interne manifestate în ţesuturi. Stabilometria studiază evoluţia în statică a centrului de presiune, definit ca originea vectorului forţei de reacţiune în raport cu baza de susţinere. Procesul de îmbătrânire sau prezenţa unor afecţiuni precum diabetul, artrita reumatoidă sau patologii de natură mecanică au ca rezultat influenţarea posturii prin creşterea instabilităţii şi a riscului de cădere. Există dovezi medicale care demonstrează efectul pozitiv al dispozitivelor medicale (încălţăminte ortopedică sau orteze) asupra posturii. În prescrierea şi evaluarea influenţei dispozitivelor medicale asupra posturii, un rol important îl ocupă stabilometria, respectiv evaluarea posturii în condiţii statice. Articolul îşi propune evaluarea principalilor parametri stabilometrici determinaţi cu ajutorul platformei de forţă AccuGait-AMTI şi corelarea acestora cu caracteristicile tehnice ale dispozitivelor medicale.

CUVINTE CHEIE: stabilometrie, postură, dispozitiv medical

\section{ÉVALUATION STABILOMÉTRIQUE: LES IMPLICATIONS POUR LA PRESCRIPTION DE DISPOSITIFS MÉDICAUX}

RÉSUMÉ. La littérature médicale définit la posture par le positionnement et l'orientation des segments de corps par rapport à la direction du champ de gravitation. L'équilibre représente toutes les actions statiques et dynamiques exercées par le corps à la suite de l'interaction entre les mécanismes de contrôle de posture afin d'éviter les chutes. Le maintien d'une position normale est une condition préalable à la réduction du stress interne qui se manifeste dans les tissus. La stabilometrie étudie l'évolution, dans des conditions statiques, du centre de pression, défini comme l'origine du vecteur de force de réaction par rapport au support. Le processus de vieillissement ou la présence de maladies telles que le diabète, la polyarthrite rhumatoïde ou pathologies de nature mécanique influencent la posture en augmentant l'instabilité et le risque de chutes. Il y a des preuves médicales qui démontrent l'effet positif des dispositifs médicaux (chaussures orthopédiques ou orthèses) sur la posture. Un rôle important dans la prescription et l'évaluation de l'influence des dispositifs médicaux sur la posture est celui de la stabilometrie, c'est-à-dire l'évaluation de la posture dans des conditions statiques. L'article propose l'évaluation des principaux paramètres stabilometriques déterminés par la plate-forme de force AccuGait-AMTI et leur corrélation avec les caractéristiques techniques des dispositifs médicaux.

MOTS CLÉS: stabilométrie, posture, dispositif médical

\footnotetext{
*Correspondence to: Gabriel STAN, Elias Emergency University Hospital, Department of Orthopedics-Traumatology, 17 Marasti Blvd., Bucharest, email: gabisus2000@yahoo.com
} 


\section{INTRODUCTION}

Posture is defined as the position and orientation of body segments relative to the direction of the gravitational field. Balance encompasses all static and dynamic actions performed by the body as a result of the interaction between control mechanisms of the central nervous system and the musculoskeletal system in order to avoid falls by maintaining the center of gravity within the limits of the support surface. There is medical evidence that demonstrates the positive effect of medical devices (medical footwear or orthoses) on posture. An important role in prescribing and assessing the influence of medical devices on posture is that of stabilometry, namely assessing posture under static conditions.

Shoes can be used in two opposite directions in relation to maintaining balance, namely:

- improving balance by increasing stability in order to decrease the risk of falls and their negative consequences on health. This direction is found especially in the situation of the elderly or those suffering from conditions such as diabetes, ostheoarthritis, neuromuscular disorders, orthopedic disorders etc.;

- improving balance by creating instability in order to exercise certain categories of muscles with an active role in increasing stability. This is the case of rocker soles, highlighting the MBT shoes solution whose design principle consists in exercising muscles less used due to modern walking conditions (especially walking on hard surfaces). Muscles are exercised by creating instability in the contact phase of gait, and the technical solution adopted for the construction of the sole is to use a combination of two materials with different hardness values, the heel being made of a lower hardness material [1]. Changing muscle activity by manipulating the trajectory of the center of pressure (COP) is another objective [2] with potential implications for improved stability. In this case the shoes working as a medical device, part of the recovery program for conditions such as patellofemoral pain syndrome or knee osteoarthritis. Sensor-motor exercises, as part of a recovery program, resort to a wide range of devices such as wobble boards, rocker soles or balance training shoes [3].

\section{INTRODUCERE}

Postura este definită prin poziţionarea şi orientarea segmentelor corporale în raport cu direcţia câmpului gravitaţional. Echilibrul reprezintă totalitatea acţiunilor statice şi dinamice efectuate de corp ca urmare a interacţiunii dintre mecanismele de control ale sistemului nervos central şi ale sistemului osteomusculo-ligamentar, cu scopul evitării căderii prin menţinerea centrului de greutate în limitele bazei de sprijin. Există dovezi medicale care demonstrează efectul pozitiv al dispozitivelor medicale (încălţăminte sau orteze pentru picior) asupra posturii. În proiectarea şi evaluarea influenţei dispozitivelor medicale asupra posturii un rol important îl ocupă stabilometria, respectiv evaluarea posturii în condiţii statice.

Încălţămintea poate fi utilizată în două direcţii opuse în relaţie cu menţinerea echilibrului, şi anume:

- îmbunătăţirea echilibrului prin creşterea stabilităţii cu scopul scăderii riscului de cădere şi a consecinţelor negative pe care acestea le au asupra sănătăţii. Această direcţie este întâlnită în special în situaţia persoanelor în vârstă sau a acelora suferind de afecţiuni precum diabet, osteoartrită, afecţiuni neuromusculare, ortopedice etc.;

- îmbunătăţirea echilibrului prin crearea unei stări de instabilitate cu scopul antrenării anumitor categorii de muşchi având un rol activ în creşterea stabilităţii. Este cazul încălţămintei cu talpă balansoar unde putem evidenţia soluţia MBT al cărei principiu de proiectare constă în antrenarea muşchilor mai puţin utilizaţi datorită condiţiilor moderne de deplasare (în special mersul pe suprafeţe dure). Antrenarea musculaturii se realizează prin crearea unei stări de instabilitate în faza de contact a mersului, soluţia tehnică adoptată pentru construcţia tălpii fiind aceea a utilizării unei combinaţii de două materiale cu durităţi diferite, tocul fiind realizat din materialul cu duritate mai mică [1]. Modificarea activităţii musculare prin manipularea traiectoriei centrului de presiune (COP) reprezintă un alt obiectiv [2] cu potenţiale implicaţii în îmbunătăţirea stabilităţii. În acest caz încălţămintea funcţionează ca un dispozitiv medical, parte integrantă a programului de recuperare al unor afecţiuni precum sindromul dureros femuro-patelar sau osteoartrită genunchiului. Exerciţiile senzori-motorii, ca parte integrantă a unui program de recuperare, fac apel la o gamă largă de dispozitive precum discurile instabile (wobble board), tălpile balansoar, sau încălţămintea 
Patients suffering from knee osteoarthritis present changes in proprioception and a reduction of mechanoreceptors surrounding ligaments [4]. The ability to control posture in these patients will also be affected by low muscle strength, especially the quadriceps, and pain. Total knee arthroplasty is a surgery commonly practiced in elderly patients with decreased mobility due to pain and muscle atrophy. These are sources of imbalance and lead to the inability to safely conduct normal activities.

The force platform is an indispensable tool for a complex posturographic assessment. Establishing an experimental protocol requires a good knowledge of both the postural parameters provided by the force platform and the correlations between these parameters and objectives established for the medical device. In this paper, the main objective considered was to evaluate postoperative stability after total knee arthroplasty surgery. Parameters correlated to maintaining balance and inferred from the trajectory of the center of pressure (COP) are sensitive enough to detect postural changes due to changing technical characteristics of medical devices [5].

The medical literature shows a number of correlations between parameters characterizing posture and their significance in terms of the activity that the body must perform to maintain or restore balance. Table 1 shows the significance of the stabilometric parameters - frequently cited in the literature and which can be measured using the force platform. pentruantrenarea echilibrului [3].

Pacienţii suferinzi de gonartroză prezintă modificări ale propriocepţiei şi o diminuare a mecanoreceptorilor din jurul ligamentelor [4]. Abilitatea de control a posturii la aceşti pacienţi va fi afectată şi datorită forţei musculare scăzute, în special a cvadricepsului, şi a durerii. Artroplastia totală de genunchi este o intervenţie ce se practică de obicei la pacienţi vârstnici cu mobilitate scăzută datorită durerii şi cu atrofii musculare. Acestea sunt cauze ale dezechilibrului şi duc la imposibilitatea de desfăşurare în condiţii de siguranţă a activităţilor obişnuite.

Platforma de forţă reprezintă un instrument indispensabil pentru o evaluare posturografică complexă. Stabilirea unui protocol de experimentare presupune o bună cunoaştere atât a parametrilor posturali ce pot fi furnizaţi de platforma de forţă, cât şi a corelaţiilor dintre aceşti parametri şi obiectivele stabilite pentru dispozitivul medical. În prezenta lucrare, obiectivul principal luat în considerare a fost evaluarea stabilităţii postoperatorie după o operaţie de artroplastie a genunchiului. Parametrii care sunt corelaţi cu menţinerea echilibrului şi sunt deduşi pe baza traiectoriei centrului de presiune (COP) sunt suficient de sensibili în detectarea modificărilor posturale datorate modificării caracteristicilor tehnice ale dispozitivelor medicale [5].

Literatura medicală prezintă o serie de corelaţii între parametrii ce caracterizează postura şi semnificaţia acestora din punctul de vedere al activităţii pe care organismul uman trebuie să o desfăşoare pentru menţinerea sau redobândirea echilibrului. În Tabelul 1 se prezintă semnificaţia unor parametri stabilometrici frecvent citaţi de literatura de specialitate şi măsurabili cu ajutorul platformei de forţă.

Table 1: Correlations between stabilometric parameters and their significance

Tabelul 1: Corelaţii între parametrii stabilometrici şi semnificaţia acestora

\begin{tabular}{|c|c|c|}
\hline $\begin{array}{l}\text { Parameter } \\
\text { Parametru }\end{array}$ & $\begin{array}{l}\text { Definition } \\
\text { Definiţie }\end{array}$ & $\begin{array}{l}\text { Significance } \\
\text { Semnificaţie }\end{array}$ \\
\hline $\begin{array}{c}\text { Protocol: } \\
\text { Narrow vs. Wide } \\
\text { base } \\
\text { Protocol: } \\
\text { baza apropiată } \\
\text { vs. baza } \\
\text { depărtată }\end{array}$ & $\begin{array}{c}\text { - Narrow base: heels and } \\
\text { first } \\
\text { metatarsophalangeal } \\
\text { joints touch } \\
\text { - Wide base: distance = } \\
17 \mathrm{~cm} \text {, angle }=14^{\circ} \\
\text { - Baza apropiată: } \\
\text { călcâiele şi art. MF I se } \\
\text { ating } \\
\text { - Baza depărtată: } \\
\text { distanţa }=17 \mathrm{~cm} \text {, unghiul } \\
\text { format }=14^{\circ}\end{array}$ & $\begin{array}{l}\text { Balance tests in narrow base position can distinguish between older persons } \\
\text { who have had more falls than those who have not fallen. In general, there is } \\
\text { an increase in center of pressure displacement for the first group, especially } \\
\text { in the medio-lateral direction [6]. } \\
\text { Testele de echilibru cu baza apropiată pot distinge între persoanele vârstnice } \\
\text { care au înregistrat mai multe căderifaţă de cele vârstnice care nu au căzut. În } \\
\text { general, în cazul primei categorii se înregistrează o creştere a deplasării } \\
\text { centrului de presiune, în special în direcţia medio-laterală [6]. }\end{array}$ \\
\hline
\end{tabular}


Table 1: Continued

Tabelul 1: Continuare

\begin{tabular}{|c|c|c|}
\hline $\begin{array}{l}\text { Parameter } \\
\text { Parametru }\end{array}$ & $\begin{array}{l}\text { Definition } \\
\text { Definiţie }\end{array}$ & $\begin{array}{l}\text { Significance } \\
\text { Semnificaţie }\end{array}$ \\
\hline $\begin{array}{l}\text { Fx vs. Time, } \\
\text { Fy vs. Time, } \\
\text { Fz vs. Time } \\
\text { Fx vs. Timp, } \\
\text { Fy vs. Timp, } \\
\text { Fz vs. Timp }\end{array}$ & $\begin{array}{c}\text { Graphs reaction force } \\
\text { components Fx, Fy, Fz } \\
\text { versus time } \\
\text { Graficele componentelor } \\
\text { forţei de reacţiune Fx, Fy, } \\
\text { Fz în funcţie de timp }\end{array}$ & $\begin{array}{l}\text { Variability of ground reaction force components in certain time intervals } \\
\text { corresponding to the test period characterize the posture adjustment process } \\
\text { due to balance of weight from one foot to the other. Variability is analyzed by } \\
\text { standard deviation for } 5 \text { time intervals corresponding to the test period. This } \\
\text { variability characterizes postural changes that occur to restore static balance, } \\
\text { changes resulting from the transfer of weight [7]. } \\
\text { Variabilitatea componentelor forţei de reacţiune din anumite intervale de timp } \\
\text { corespunzătoare perioadei de testare caracterizează procesul de ajustare a } \\
\text { posturii datorat balansului greutăţii de pe un picior pe celălalt. Variabilitatea } \\
\text { este analizată prin intermediul deviaţiei standard pentru } 5 \text { intervale de timp } \\
\text { corespunzătoare perioadei de probă. Această variabilitate caracterizează } \\
\text { modificările posturale ce au loc pentru refacerea echilibrului static, modificări } \\
\text { rezultate din transferul greutăţii [7]. }\end{array}$ \\
\hline FFT-COPX & $\begin{array}{l}\text { FFT-COPX is the graph of } \\
\text { Fourier transform of the } \\
\text { x coordinate of the } \\
\text { center of pressure } \\
\text { trajectory. } \\
\text { FFT-COPX reprezintă } \\
\text { graficul transformatei } \\
\text { Fourier a coordonatei x a } \\
\text { traiectoriei centrului de } \\
\text { presiune. }\end{array}$ & $\begin{array}{l}\text { Fourier transform of a signal is the decomposition of the signal into a sum of } \\
\text { sine and cosine functions characterized by different amplitudes and } \\
\text { frequencies. This process is also known as spectral analysis. The predominant } \\
\text { frequency or maximum frequency corresponds to the component with the } \\
\text { maximum amplitude of the entire spectrum. The band with } 80 \% \text { of the power } \\
\text { spectrum best characterizes postural control system changes [8]. } \\
\text { Transformata Fourier a unui semnal reprezintă descompunerea acestui } \\
\text { semnal într-o sumă de funcţii sinus şi cosinus caracterizate prin diferite } \\
\text { amplitudini şi frecvenţe. Acest proces mai este cunoscut sub denumirea de } \\
\text { analiză spectrală. Frecvenţa predominantă sau frecvenţa maximă corespunde } \\
\text { componentei cu amplitudine maximă din întregul spectru. Banda de frecvenţe } \\
\text { având 80\% din spectrul de putere caracterizează cel mai bine modificările } \\
\text { sistemuluide controlpostural[8]. }\end{array}$ \\
\hline $\begin{array}{l}\text { The maximum } \\
\text { speed of the } \\
\text { center of } \\
\text { pressure } \\
\text { Viteza maximă a } \\
\text { centrului de } \\
\text { presiune }\end{array}$ & $\begin{array}{l}\text { It respresents the } \\
\text { maximum value of the } \\
\text { speed of the center of } \\
\text { pressure } \\
\text { Reprezintă valoarea } \\
\text { maximă a vitezei } \\
\text { centrului de presiune }\end{array}$ & $\begin{array}{l}\text { It is a good indicator of the effort required to maintain stability [10]. } \\
\text { Reprezintă un bun indicator al necesarului de efort cerut de menţinerea } \\
\text { stabilităţii [10]. }\end{array}$ \\
\hline $\begin{array}{l}\text { Average speed } \\
\quad(\mathrm{cm} / \mathrm{s}) \\
\text { Viteza medie } \\
\quad(\mathrm{cm} / \mathrm{s})\end{array}$ & $\begin{array}{l}\text { The ratio of the sway } \\
\text { length and time of } \\
\text { measurement } \\
\text { Reprezintă raportul } \\
\text { dintre lungimea } \\
\text { traiectoriei centrului de } \\
\text { presiune şi timpul de } \\
\text { măsurare }\end{array}$ & $\begin{array}{l}\text { The average speed of the center of pressure is a major determinant for balance } \\
\text { maintaining, representing a parameter sensitive to the central nervous system } \\
\text { activities performed to maintain posture. In the case of imbalances, } \\
\text { intensified re-balancing efforts are reflected by a high average speed needed } \\
\text { to restore posture [9]. Also, this parameter characterizes the overall postural } \\
\text { performance, being associated with risk of falls [10]. It is influenced by age, } \\
\text { presence or absence of visual information or the type of footwear worn. } \\
\text { Viteza medie a centrului de presiune este un determinant major al activităţii de } \\
\text { menţinere a echilibrului, reprezentând un parametru sensibil la activităţile } \\
\text { sistemului nervos central efectuate pentru menţinerea posturii. În cazul unor } \\
\text { dezechilibre, eforturile de re-echilibrare mai intense sunt reflectate printr-o } \\
\text { viteză medie ridicată necesară pentru restabilirea posturii [9]. De asemenea, } \\
\text { acest parametru este un parametru care caracterizează performanţa } \\
\text { posturală generală, fiind asociat cu riscul de cădere [10]. Este influenţat de } \\
\text { vârstă, prezenţa sau absenţa informaţiilor vizuale sau tipul de încălţăminte } \\
\text { purtat. }\end{array}$ \\
\hline
\end{tabular}


Table 1: Continued

Tabelul 1: Continuare

\begin{tabular}{|c|c|c|}
\hline $\begin{array}{l}\text { Parameter } \\
\text { Parametru }\end{array}$ & $\begin{array}{l}\text { Definition } \\
\text { Definiţie }\end{array}$ & $\begin{array}{l}\text { Significance } \\
\text { Semnificaţie }\end{array}$ \\
\hline $\begin{array}{l}\text { Sway length } \\
\text { Lungimea } \\
\text { traiectoriei } \\
\text { Centrului de } \\
\text { presiune (COP) }\end{array}$ & $\begin{array}{l}\text { It represents the total } \\
\text { distance covered by the } \\
\text { COP during the test } \\
\text { period } \\
\text { Reprezintă distanţa } \\
\text { totală parcursă de COP } \\
\text { în timpul perioadei de } \\
\text { testare }\end{array}$ & \multirow{2}{*}{$\begin{array}{l}\text { For subjects with neurological conditions, medical literature shows a } \\
\text { correlation between sway speed (which is correlated with the sway length) } \\
\text { and sway area with different physiological processes involved in balance } \\
\text { control. } \\
\text { Thus, patients having vestibular system-related conditions respond by a } \\
\text { greater sway area than normal patients, while patients with proprioceptive } \\
\text { conditions showa higher sway length than normal subjects [11]. } \\
\text { În cazul unor subiecţi cu afecţiuni neurologice, literatura medicală } \\
\text { demonstrează existenţa unei corelaţii între viteza de balans (care este corelată } \\
\text { cu lungimea traiectoriei) şi aria de balans cu procese fiziologice diferite } \\
\text { implicate în controlulechilibrului. } \\
\text { Astfel, pacienţii având în principal afecţiuni la nivelul sistemului vestibular } \\
\text { răspund printr-o arie de balans mai mare decât cei normali, în timp ce pacienţii } \\
\text { cu afecţiuni proprioceptive demonstrează o mai mare lungime a traiectoriei } \\
\text { coPdecâtsubiecţiinormali [11]. }\end{array}$} \\
\hline $\begin{array}{c}\text { Sway area } \\
\text { Aria de balans }\end{array}$ & $\begin{array}{l}\text { It is the surface area that } \\
\text { encloses the sway length } \\
\text { in both } x \text {, y directions } \\
\text { Reprezintă aria } \\
\text { suprafeței care } \\
\text { incadrează traiectoria } \\
\text { centrului de presiune în } \\
\text { ambele direcţii } x, y\end{array}$ & \\
\hline $\begin{array}{l}\text { Medio-lateral or } \\
\text { antero-posterior } \\
\text { displacement } \\
\text { Deplasarea } \\
\text { medio-laterală } \\
\text { sau } \\
\text { anteroposterioară }\end{array}$ & $\begin{array}{l}\text { Measures the amplitude } \\
\text { of COP movements in } \\
\text { medio-lateral (ML Sway) } \\
\text { or anterior-posterior (AP } \\
\text { Sway) direction } \\
\text { Măsoară amplitudinea } \\
\text { mişcărilor COP în } \\
\text { direcţiile medio-laterală } \\
\text { (ML Sway) sau antero- } \\
\text { posterioară (AP Sway) }\end{array}$ & $\begin{array}{l}\text { - it is correlated with the effectiveness of postural control, } \\
\text { - it provides an image of the neuromuscular response to postural imbalances, } \\
\text { - it is an indicator of the risk of falling [13]. } \\
\text { - este corelată cu eficacitatea sistemului de control postural, } \\
\text { - reprezintă o imagine a răspunsului neuromuscular la dezechilibrele } \\
\text { posturale, } \\
\text { - este un indicator al riscului de cădere [13]. }\end{array}$ \\
\hline $\begin{array}{c}\text { Romberg } \\
\text { quotient, QR } \\
\text { QR, Coeficientul } \\
\text { Romberg }\end{array}$ & Q & $\begin{array}{l}\text { - it is expressed by the ratio of the considered parameter, } P \text {, measured with } \\
\text { eyes closed (ec = eyes closed) and the same parameter measured with eyes } \\
\text { open (eo = eyes opened) } \\
\text { - it is the most widely used index for assessing the influence of the visual } \\
\text { system in the study of postural performance. Measurements are performed in } \\
\text { the order: eyes opened-eyes closed. } \\
\text { - este exprimat prin raportul dintre valoarea parametrului considerat, P, } \\
\text { măsurat cu ochii închişi (ec = eyes closed) şi valoarea aceluiaşi parametru } \\
\text { măsuratcu ochii deschişi (eo = eyesopened), } \\
\text { - reprezintă cel mai utilizat index pentru evaluarea influenţei sistemului } \\
\text { vizual în studiul performanţei posturale. Măsurătorile sunt efectuate în } \\
\text { ordinea: ochi deschişi-ochi închişi. }\end{array}$ \\
\hline $\begin{array}{l}\text { Time-to-boundary } \\
\text { (TTB) } \\
\text { Timpul până la } \\
\text { depăşirea } \\
\text { marginii bazei de } \\
\text { sprijin (TTB) }\end{array}$ & $\begin{array}{l}\text { It estimates the time for } \\
\text { the center of pressure to } \\
\text { reach the edge of the } \\
\text { support area at a speed } \\
\text { equal to the existing } \\
\text { speed at a given moment } \\
\text { Estimează timpul în care } \\
\text { centrul de presiune va } \\
\text { atinge marginea bazei de } \\
\text { sprijin la o viteză egală } \\
\text { cu viteza existent ă la } \\
\text { momentul dat }\end{array}$ & $\begin{array}{l}\text { Decreased TTB values and variability reflect a low postural control. This } \\
\text { parameter was found to be more sensitive in detecting low postural control } \\
\text { associated with wearing different types of shoes, having as distinctive } \\
\text { elements insoles with textured surfaces or heels with different volumes. Thus } \\
\text { insoles with textured surfaces produced a significant decrease in the value and } \\
\text { variability of TTB in the medio-lateral direction [14]. } \\
\text { Valorile şi variabilitatea scăzute ale TTB reflectă un control postural scăzut. } \\
\text { Acest parametru s-a dovedit a fi mai sensibil în detectarea unui control } \\
\text { postural scăzut asociat cu purtarea unor tipuri diferite de încălţăminte, având } \\
\text { ca elemente distinctive branţuri cu suprafeţe cu texturi diferite sau tocuri de } \\
\text { volume diferite. Astfel branţurile cu suprafeţe texturate au produs o scădere } \\
\text { semnificativăa valoriişsi variabilităţii TTB în direcţia medio-laterală [14]. }\end{array}$ \\
\hline
\end{tabular}


There are many attempts to standardize stabilometric testing procedures. The process turns out to be difficult if we consider, for example, only the position of the feet. Thus, for the wide base position, the distance between the heels ranges between 2 and $17 \mathrm{~cm}$ depending on various anthropometric parameters, while the angle variation between the medial sides of the feet ranges between 14 and $30^{\circ}[7$, $12,15,16]$.

\section{EXPERIMENTAL. STABILOMETRIC ASSESSMENT}

In this preliminary set of measurements two subjects were selected, whose data are presented in Table 2. These measurements were performed in a lengthy evaluation of the use of force platform in order to make the results of total knee arthroplasty surgery objective.
Există numeroase încercări de standardizare ale procedurilor de testare stabilometrică. Procesul se dovedeşte a fi unul dificil dacă luăm în considerare, spre exemplu, numai poziţia picioarelor. Astfel, pentru baza depărtată întâlnim valori ale distanţei dintre călcâie între 2 şi $17 \mathrm{~cm}$ în funcţie de diverşi parametri antropometrici, în timp ce unghiul dintre laturile mediale ale picioarelor domeniul de variaţie este cuprins între $14-30^{\circ}[7,12,15,16]$.

\section{PARTEA EXPERIMENTALĂ. EVALUARE STABILOMETRICĂ}

În cadrul acestui set preliminar de măsurători au fost selectaţi doi subieç̧i ale căror date sunt prezentate în Tabelul 2. Aceste măsurători au fost efectuate în cadrul unei evaluări de lungă durată a utilizării platformei de forţă pentru obiectivizarea rezultatelor unei intervenţii chirurgicale de artroplastie a genunchiului.

Table 2: Characteristics of subjects

Tabelul 2: Caracteristicile subiecţilor

\begin{tabular}{|c|c|c|c|c|c|c|}
\hline $\begin{array}{c}\text { Subject } \\
\text { Subiect }\end{array}$ & $\begin{array}{c}\text { Age } \\
\text { Vârstă }\end{array}$ & $\begin{array}{c}\text { Gender } \\
\text { Sex }\end{array}$ & $\begin{array}{c}\text { Height, meters } \\
\text { Inălţime, metri }\end{array}$ & $\begin{array}{c}\text { Preoperative } \\
\text { weight, N } \\
\text { Greutatea } \\
\text { preoperator, N }\end{array}$ & $\begin{array}{c}\text { BMI } \\
\text { IMC }\end{array}$ & $\begin{array}{c}\text { Foot morphology } \\
\text { Morfologie picior }\end{array}$ \\
\hline $\begin{array}{c}\text { Subject no. 1, S1 } \\
\text { Subiectul nr. 1, S1 }\end{array}$ & 65 & $\begin{array}{c}\text { female } \\
\text { feminin }\end{array}$ & 1.65 & 744.1 & 27.9 & $\begin{array}{c}\text { Flat foot, unilateral HAV } \\
\text { Picior plat, HAV unilateral }\end{array}$ \\
\hline $\begin{array}{c}\text { Subject no. 2, S2 } \\
\text { Subiectul nr. 2, S2 }\end{array}$ & 55 & $\begin{array}{c}\text { female } \\
\text { feminin }\end{array}$ & 1.63 & 547.6 & 21.0 & $\begin{array}{c}\text { Apparently normal foot } \\
\text { Picior aparent normal }\end{array}$ \\
\hline
\end{tabular}

The established protocol for performing measurements was the following:

- Bilateral orthostatic position, without shoes, on the AccuGait-AMTI force platform:

- conditions: eyes closed (EC) and eyes open (EO). Order of measurements was: eyes open (3 tests) followed by eyes closed ( 3 tests);

- recording time $=30 \mathrm{~s}$.;

- number of tests $=3$ for each condition;

- feet position = narrow base;

- arm position $=$ normal, arms at the sides. The subject is focusing towards an achromatic circle with a diameter of $5 \mathrm{~cm}$, placed at eye level at a distance of 1 meter from the subject;
Protocolul stabilit pentru efectuarea măsurătorilor a fost următorul:

- Poziţie ortostatică bilaterală, fără încălţăminte pe platforma de forţă AccuGait-AMTI:

- condiţii: ochi închişi (EC) şi ochi deschişi (EO). Ordinea de efectuare a măsurătorilor a fost: ochi deschişi (3 probe) urmată de ochi închişi (3 probe);

- timp de înregistrare=30 s.;

- numărul de probe = 3 pentru fiecare condiţie;

- poziţia picioarelor = baza apropiată;

- poziţia braţelor = normală, pe lângă corp. Privirea îndreptată către un cerc acromatic cu diametrul de $5 \mathrm{~cm}$, plasat la nivelul ochilor, la o distanţă de 1 metru de subiect; 
- recording frequency $=100 \mathrm{~Hz}$;

- signal filtering frequency $=5 \mathrm{~Hz}$;

- 3 measurement sessions were conducted: preoperative (Pre), postoperative (Pos - after about 1 week) and after a recovery period (Rec about 1 month).

Subjects were explained the experimental conditions in detail and signed the informed consent form. Enough time to practice measuring conditions and enough time for rest after each test were allowed. During tests with eyes closed, a person was present next to the subject so as to avoid any events generated by a potential imbalance and fall. During the three sessions of measurements no incident posing a potential risk to subjects falling was recorded.

\section{RESULTS AND DISCUSSIONS}

The results are presented in Tables 3, 4 and 5 and in Figures 1 and 2. For the "eyes open" condition, data for subject no. 1 indicate an increase in stability after the recovery period, demonstrated by the lower values recorded for all selected parameters compared to session no. 1 -"preoperative". The medio-lateral displacement shows a decrease of $32.02 \%$, the anterior-posterior of $33.05 \%$, while the ellipse area comprising $95 \%$ of the data (Figure 2) recorded a decrease of $126.29 \%$ (Table 5, Figure 2).
- frecvenţa de înregistrare $=100 \mathrm{~Hz}$;

- frecvenţa de filtrare a semnalului $=5 \mathrm{~Hz}$;

- au fost efectuate 3 sesiuni de măsurători: preoperator (Pre), postoperator (Pos - după aproximativ 1 săptămână) şi după o perioadă de recuperare (Rec-de aproximativ 1 lună).

Subiecţilor li s-au explicat în detaliu condiţiile experimentale şi au semnat Fişa de consimţământ informat. A fost acordat un timp suficient de practică a condiţiilor de măsurare şi după fiecare probă, suficient timp pentru odihnă. În timpul probelor cu ochii închişi a fost asigurată prezenţa unei persoane lângă subiect, astfel încât să fie evitate orice evenimente generate de o potenţială dezechilibrare şi cădere. În timpul celor 3 sesiuni de măsurători nu a fost înregistrat niciun incident care să reprezinte un potenţial risc de cădere pentru subiecţi.

\section{REZULTATE ŞI DISCUTII}

Rezultatele obţinute sunt prezentate în Tabelele 3, 4 şi 5 şi Figurile 1 şi 2 . Din punctul de vedere al condiţiei „ochii deschişi", datele pentru subiectul nr. 1 indică o creştere a stabilităţii după perioada de recuperare, demonstrată de valorile mai scăzute înregistrate pentru toţi parametrii selectaţi comparativ cu sesiunea nr. $1=$ "preoperator". Astfel, deplasarea medio-laterală prezintă o scădere cu $32.02 \%$, cea antero-posterioara de $33.05 \%$, în timp ce aria elipsei cuprinzând 95\% dintre date (Figura 2) a înregistrat o diminuare cu 126.29\% (Tabelul 5, Figura 2).

Table 3: Variables selected for analysis for the 3 work sessions: preoperative, postoperative and recovery.

Average, standard deviation and coefficient of variation - subject no. 1

Tabelul 3: Variabilele selectate pentru analiză pentru cele 3 sesiuni de lucru: preoperator, postoperator şi recuperare. Media, deviaţia standard şi coeficientul de variaţie - subiectul nr. 1

\begin{tabular}{|c|c|c|c|c|c|c|c|c|c|c|c|c|c|}
\hline & & \multicolumn{3}{|c|}{ PREoperator } & & \multicolumn{3}{|c|}{ POSToperator } & & \multicolumn{3}{|c|}{ Recuperare } & \\
\hline & & $\mathrm{X}=\mathrm{ML}$ & $Y=A P$ & & & $\mathrm{X}=\mathrm{ML}$ & $Y=A P$ & & & $\mathrm{X}=\mathrm{ML}$ & $Y=A P$ & & \\
\hline \multicolumn{2}{|c|}{ SUBIECTUL NR.1 } & ML-Xrange & AP-Yrange & V Avg & Area95 & ML-Xrange & AP-Yrange & V Avg & Area95 & ML-Xrange & AP-Yrange & V Avg & Area95 \\
\hline \multirow[t]{2}{*}{ Condition } & Trial & $\mathrm{cm}$ & $\mathrm{cm}$ & $\mathrm{cm} / \mathrm{sec}$ & $\mathrm{cm} \mathrm{sq}$ & $\mathrm{cm}$ & $\mathrm{cm}$ & $\mathrm{cm} / \mathrm{sec}$ & $\mathrm{cm} \mathrm{sq}$ & $\mathrm{cm}$ & $\mathrm{cm}$ & $\mathrm{cm} / \mathrm{sec}$ & $\mathrm{cm} \mathrm{sq}$ \\
\hline & 1 & 5.31 & 2.98 & 3.05 & 12.83 & 2.72 & 2.58 & 1.80 & 4.99 & 2.48 & 2.18 & 2.72 & 3.38 \\
\hline \multirow[t]{5}{*}{ EOCB } & 2 & 3.28 & 3.04 & 2.72 & 8.86 & 2.84 & 1.73 & 1.90 & 3.66 & 3.67 & 2.60 & 2.87 & 5.44 \\
\hline & 3 & 3.12 & 3.44 & 2.82 & 7.32 & 2.42 & 2.65 & 2.00 & 4.72 & 2.72 & 2.33 & 2.71 & 4.00 \\
\hline & MEDIA EO & 3.90 & 3.15 & 2.86 & 9.67 & 2.66 & 2.32 & 1.90 & 4.46 & 2.96 & 2.37 & 2.77 & 4.27 \\
\hline & Stdev & 1.22 & 0.25 & 0.17 & 2.84 & 0.22 & 0.51 & 0.10 & 0.70 & 0.63 & 0.21 & 0.09 & 1.06 \\
\hline & $\mathrm{Cv}$ & 31.28 & 7.93 & 5.91 & 29.40 & 8.13 & 22.08 & 5.26 & 15.77 & 21.28 & 8.98 & 3.24 & 24.73 \\
\hline & 1 & 3.26 & 2.58 & 2.86 & 5.87 & 5.31 & 3.89 & 2.80 & 12.28 & 6.00 & 5.88 & 4.54 & 15.96 \\
\hline \multirow[t]{2}{*}{$E C C B$} & 2 & 5.08 & 3.86 & 2.87 & 9.04 & 5.33 & 4.12 & 2.93 & 12.34 & 4.38 & 4.78 & 4.01 & 12.82 \\
\hline & 3 & 3.10 & 2.81 & 2.76 & 5.29 & 5.84 & 4.20 & 3.33 & 19.32 & 6.24 & 5.27 & 4.54 & 22.26 \\
\hline \multirow{2}{*}{\multicolumn{2}{|c|}{$\begin{array}{r}\text { MEDIA EC } \\
\text { Stdev }\end{array}$}} & 3.81 & 3.08 & 2.83 & 6.73 & 5.49 & 4.07 & 3.02 & 14.65 & 5.54 & 5.31 & 4.36 & 17.01 \\
\hline & & 1.10 & 0.68 & 0.06 & 2.02 & 0.30 & 0.16 & 0.28 & 4.05 & 1.01 & 0.55 & 0.31 & 4.81 \\
\hline \multicolumn{2}{|r|}{$\mathrm{Cv}$} & 28.84 & 22.13 & 2.15 & 29.98 & 5.47 & 3.95 & 9.15 & 27.63 & 18.26 & 10.38 & 7.01 & 28.26 \\
\hline \multicolumn{2}{|r|}{ ROMBERG } & 0.98 & 0.98 & 0.99 & 0.70 & 2.07 & 1.75 & 1.59 & 3.29 & 1.87 & 2.24 & 1.58 & 3.98 \\
\hline
\end{tabular}


In the absence of information provided by the visual system, in the "eyes closed" condition, the data indicate an increase in instability both for postoperative compared to preoperative, and after recovery compared to preoperative. Thus, confronting results after recovery compared to preoperative, there is an increase of $31.17 \%$ in the medio-lateral displacement, of $41.93 \%$ in anteriorposterior displacement, while the average speed of COP increases by $35.14 \%$, and area of the ellipse by $60.42 \%$.
În absenţa informaţiilor oferite de sistemul vizual, în condiţia „ochi închişi”, datele indică o creştere a instabilităţii, atât postoperator faţă de preoperator, cât şi după recuperare faţă de preoperator. Astfel, comparând rezultatele după recuperare faţă de preoperator, obţinem o creştere de $31.17 \%$ a deplasării medio-laterale, de $41.93 \%$ pentru deplasarea anteroposterioară, în timp ce viteza medie a COP creşte cu $35.14 \%$, iar aria elipsei, cu $60.42 \%$.

Table 4: Variables selected for analysis for the 3 work sessions: preoperative, postoperative and recovery.

Average, standard deviation and coefficient of variation - subject no. 2

Tabelul 4: Variabilele selectate pentru analiză pentru cele 3 sesiuni de lucru: preoperator, postoperator şi recuperare. Media, deviaţia standard şi coeficientul de variaţie - subiectul nr. 2

\begin{tabular}{|c|c|c|c|c|c|c|c|c|c|c|c|c|c|}
\hline & & \multicolumn{3}{|c|}{ PREoperator } & & \multicolumn{3}{|c|}{ POSToperator } & & \multicolumn{3}{|c|}{ Recuperare } & \\
\hline & & $\mathrm{X}=\mathrm{ML}$ & $Y=A P$ & & & $\mathrm{X}=\mathrm{ML}$ & $Y=A P$ & & & $\mathrm{X}=\mathrm{ML}$ & $Y=A P$ & & \\
\hline \multicolumn{2}{|c|}{ SUBIECTUL NR. 2} & ML-Xrange & AP-Yrange & V Avg & Area95 & ML-Xrange & AP-Yrange & V Avg & Area95 & ML-Xrange & AP-Yrange & V Avg & Area95 \\
\hline Condition & Trial & $\mathrm{cm}$ & $\mathrm{cm}$ & $\mathrm{cm} / \mathrm{sec}$ & $\mathrm{cm} \mathrm{sq}$ & $\mathrm{cm}$ & $\mathrm{cm}$ & $\mathrm{cm} / \mathrm{sec}$ & $\mathrm{cm} \mathrm{sq}$ & $\mathrm{cm}$ & $\mathrm{cm}$ & $\mathrm{cm} / \mathrm{sec}$ & $\mathrm{cm} \mathrm{sq}$ \\
\hline & 1 & 2.02 & 2.39 & 1.62 & 3.91 & 1.98 & 2.56 & 2.02 & 2.88 & 2.49 & 1.95 & 1.99 & 4.17 \\
\hline EOCB & 2 & 2.53 & 2.68 & 1.62 & 5.23 & 2.27 & 3.81 & 2.62 & 4.31 & 2.82 & 2.51 & 2.03 & 5.07 \\
\hline & 3 & 2.85 & 2.13 & 1.64 & 4.13 & 2.38 & 2.91 & 2.05 & 3.47 & 2.41 & 2.36 & 1.81 & 4.38 \\
\hline \multirow{3}{*}{\multicolumn{2}{|c|}{$\begin{array}{r}\text { MEDIA EO } \\
\text { Stdev } \\
\mathrm{Cv} \\
\end{array}$}} & 2.47 & 2.40 & 1.63 & 4.42 & 2.21 & 3.09 & 2.23 & 3.55 & 2.57 & 2.27 & 1.94 & 4.54 \\
\hline & & 0.42 & 0.28 & 0.01 & 0.71 & 0.21 & 0.64 & 0.34 & 0.72 & 0.22 & 0.29 & 0.12 & 0.47 \\
\hline & & 16.97 & 11.46 & 0.71 & 15.99 & 9.35 & 20.85 & 15.16 & 20.22 & 8.45 & 12.75 & 6.03 & 10.37 \\
\hline & 1 & 4.80 & 3.19 & 2.87 & 8.50 & 3.83 & 3.90 & 3.73 & 9.49 & 2.35 & 2.60 & 2.52 & 3.29 \\
\hline \multirow[t]{2}{*}{$E C C B$} & 2 & 5.13 & 2.68 & 2.95 & 11.26 & 2.63 & 2.47 & 2.82 & 4.80 & 3.03 & 2.68 & 2.72 & 5.53 \\
\hline & 3 & 3.70 & 2.45 & 2.48 & 5.98 & 2.74 & 2.94 & 3.07 & 6.14 & 4.33 & 3.49 & 3.26 & 8.00 \\
\hline \multirow{4}{*}{\multicolumn{2}{|c|}{$\begin{array}{r}\text { MEDIA EC } \\
\text { Stdev } \\
\mathrm{CV} \\
\text { ROMBERG }\end{array}$}} & 4.54 & 2.77 & 2.77 & 8.58 & 3.07 & 3.10 & 3.21 & 6.81 & 3.24 & 2.92 & 2.83 & 5.61 \\
\hline & & 0.75 & 0.38 & 0.25 & 2.64 & 0.66 & 0.73 & 0.47 & 2.42 & 1.01 & 0.49 & 0.38 & 2.36 \\
\hline & & 16.48 & 13.66 & 9.09 & 30.78 & 21.63 & 23.49 & 14.66 & 35.47 & 31.08 & 16.84 & 13.51 & 42.02 \\
\hline & & 1.84 & 1.16 & 1.70 & 1.94 & 1.39 & 1.00 & 1.44 & 1.92 & 1.26 & 1.29 & 1.46 & 1.23 \\
\hline
\end{tabular}

Data for subject no. 2 show a different behaviour compared to the first subject. Thus by comparing the data from the recovery period with the preoperative, in the presence of visual information, there was an increase of $4.15 \%$ in the medio-lateral displacement, a decrease of $5.57 \%$ in the anterior-posterior displacement, an increase of $16.30 \%$ of average speed and an increase of $2.57 \%$ in the ellipse area. In the absence of visual information, an increased stability is noticed compared to subject no. 1 , as evidenced by the decrease of $40.37 \%$ in the medio-lateral displacement and of $53.03 \%$ in the ellipse area, given that the antero-posterior displacement and average speed had slight increases of 5.13 and $2.35 \%$, respectively (Table 5, Figure 2 ).
Datele pentru subiectul nr. 2 indică un comportament diferit faţă de primul subiect. Astfel comparând datele după perioada de recuperare cu cele preoperatorii, în prezenţa informaţiilor vizuale, s-a înregistrat o creştere cu $4.15 \%$ a deplasării mediolaterale, o scădere cu $5.57 \%$ a deplasării anteroposterioare, o creştere cu $16.30 \%$ a vitezei medii şi o creştere de $2.57 \%$ a ariei elipsei. În absenţa informaţiilor vizuale se observă o creştere a stabilităţii comparativ cu subiectul nr. 1, evidenţiată de scăderea cu $40.37 \%$ a deplasării medio-laterale şi a ariei elipsei cu 53.03\%, în condiţiile în care deplasarea anteroposterioară şi viteza medie au avut creşteri mici, de 5.13 şi respectiv de $2.35 \%$ (Tabelul 5, Figura 2). 
Table 5: Relative variation of selected stabilometric parameters

Tabelul 5: Variaţia relativă a parametrilor stabilometrici selectaţi

\begin{tabular}{|l|r|r|r|r|r|r|r|r|}
\hline & \multicolumn{4}{|c|}{ EC- OCHI DESCHISI } & \multicolumn{3}{|c|}{ EC- OCHI INCHISI } \\
\cline { 2 - 10 } Subiectul nr. 1 & ML-Xrange & AP-Yrange & V Avg & Area95 & ML-Xrange & AP-Yrange & V Avg & Area95 \\
\hline Preop/ Postop & -46.74 & -35.92 & -50.70 & -116.98 & 30.58 & 24.24 & 6.29 & 54.03 \\
\hline Postop/Rec & 10.03 & 2.11 & 31.33 & -4.29 & 0.84 & 23.35 & 30.79 & 13.91 \\
\hline Preop/Rec & -32.02 & -33.05 & -3.49 & -126.29 & 31.17 & 41.93 & 35.14 & 60.42 \\
\hline Subiectul nr. 2 & ML-Xrange & AP-Yrange & V Avg & Area95 & ML-Xrange & AP-Yrange & V Avg & Area95 \\
\hline Preop/ Postop & -11.61 & 22.41 & 27.06 & -24.48 & -48.15 & 10.63 & 13.72 & -25.99 \\
\hline Postop/Rec & 14.12 & -36.07 & -14.75 & 21.73 & 5.25 & -6.16 & -13.18 & -21.46 \\
\hline Preop/Rec & 4.15 & -5.57 & 16.30 & 2.57 & -40.37 & 5.13 & 2.35 & -53.03 \\
\hline
\end{tabular}

Note: "+" = increase in session 2 (ex. recovery) in relation to session 1 (ex. preoperative); "-"= decrease in session 2 in relation to session 1 Semnificaţii: " $t^{\prime \prime}=$ creştere în sesiunea 2 (ex. recuperare) în raport cu sesiunea 1 (ex. preoperator); "-" = descreştere în sesiunea 2 în raport cu sesiunea 1

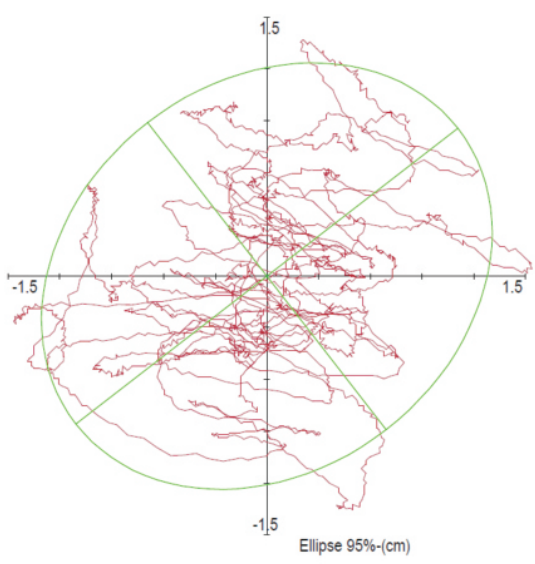

a)

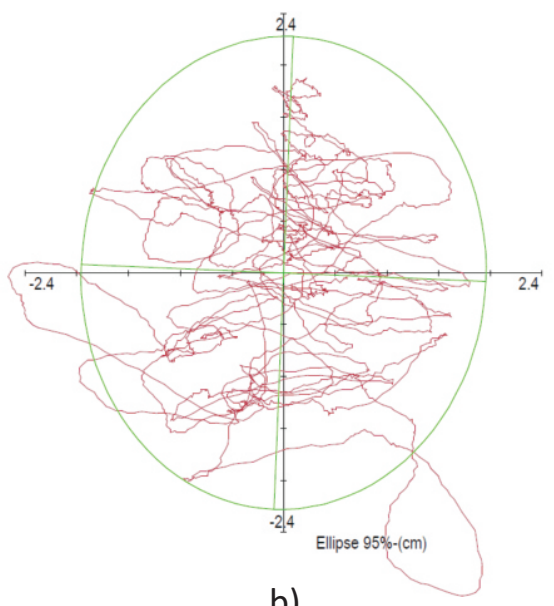

b)

Figure 1. Example for ellipse comprising 95\% of data for the "eyes closed" condition:

a) preoperative, b) after recovery period

Figura 1. Exemplu pentru elipsa conţinând 95\% dintre date pentru condiţia „ochi închişi”:

a) preoperator, b) după perioada de recuperare

Rome [17] has shown that rigid medical devices (hardness of $70^{\circ}$ - without specifying the hardness scale) placed inside the shoes can improve postural control in 4 weeks for subjects with overpronated feet, such as subject no. 1. The explanation of this effect is that by stabilizing the hindfoot and limiting overpronation, a greater control is exerted over internal rotation of the tibia, and therefore, of the knee, implicitly leading to improved balance. Menz and Lord [18] take into account a number of shoe design parameters that can lead to an improved balance
Rome [17] a demonstrat faptul că dispozitivele medicale rigide (duritate $70^{\circ}$ - fără a se preciza scala de duritate) introduse în încălţăminte pot îmbunătăţi controlul postural în timp de 4 săptămâni pentru subiecţii având picioare excesiv pronate, cum este cazul subiectului nr. 1. Explicaţia acestui efect consta în faptul că prin stabilizarea retropiciorului şi limitarea pronaţiei excesive se exercită un control mai mare asupra rotaţiei interne a tibiei şi, implicit, a genunchiului şi, în consecinţă, contribuie la îmbunătăţirea echilibrului. Menz şi Lord [18] iau în calcul o serie de parametri constructivi ai încălţămintei care pot influenţa îmbunătăţirea echilibrului prin controlul frecării cu 
through control of friction with the support area, influencing moments of motion in the foot joints through geometric design parameters or through characteristics of the materials used in sole design.

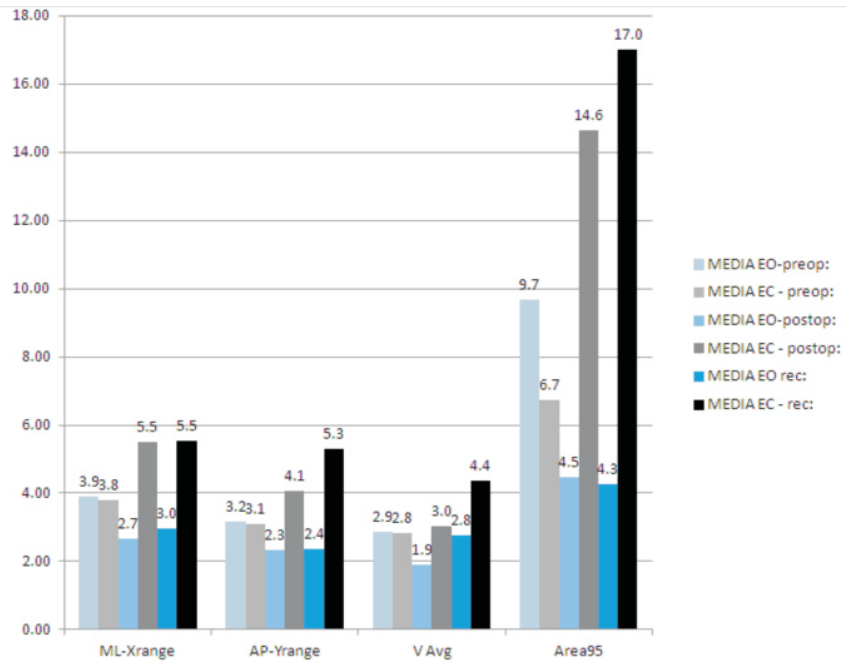

a) suprafaţa de sprijin, influențarea momentelor de mişcare din articulaţiile piciorului prin parametrii geometrici constructivi sau prin caracteristicile materialelor utilizate la proiectarea tălpii.

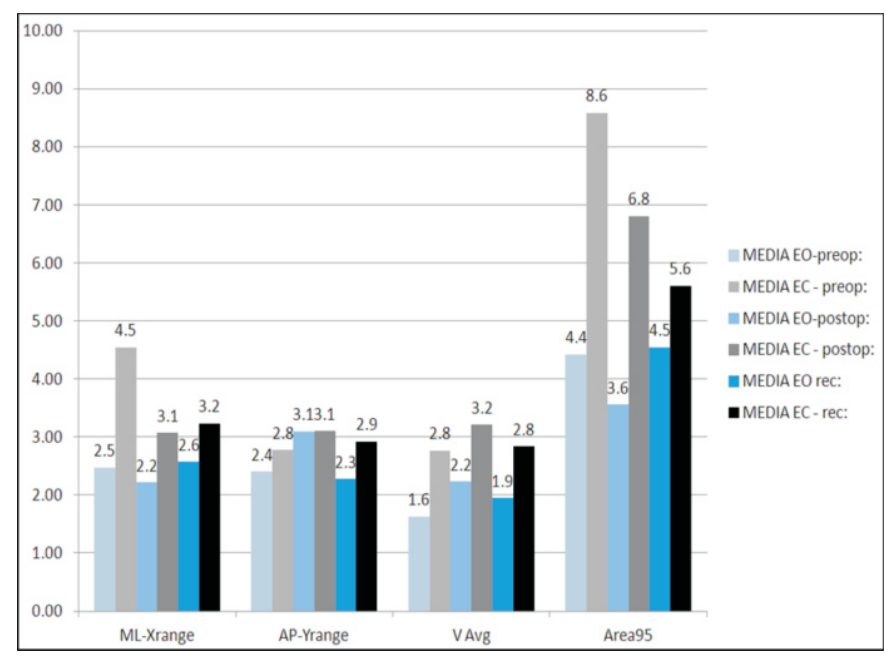

b)

Figure 2. Variation of selected values for the 3 work sessions preoperative, postoperative and recovery: a) subject 1, b) subject 2 Figura 2. Variaţia valorilor selectate pentru cele 3 sesiuni de lucru preoperator, postoperator şi recuperare: a) subiectul 1, b) subiectul 2

The number of subjects analyzed in this paper is very small - only 2 subjects - which prevents the formulation of general conclusions. Furthermore, the data reveals a contradictory behavior between the two subjects, which can be explained by the difference between the foot morphology of the 2 subjects (subject 1 has a flat foot with advanced hallux valgus in the right foot, while subject no. 2 has an apparently normal foot). Although the number of subjects participating in this study is small, it should be considered that in the normal activity of a clinic, the specialist should be able to form a treatment plan starting from the individual and sometimes contradictory results obtained from testing. The presented results indicate an improved balance for subject no. 2 compared to subject no. 1 . Based on data from the medical literature it is recommended that subject no.1 be prescribed a medical device - therapeutic shoes or foot orthoses to improve balance in particular by reducing the medio-
Numărul de subiecţi analizaţi în această lucrare este foarte mic - doar 2 subiecţi - ceea ce împiedică formularea unor concluzii generale. Mai mult, datele relevă un comportament contradictoriu între cei doi subiecţi, comportament care poate fi explicat şi prin diferenţa dintre morfologia picioarelor celor 2 subiecţi (subiectul 1 prezintă un picior plat cu halux valgus avansat la piciorul drept, în timp ce piciorul subiectului nr. 2 este aparent normal). Deşi numărul subiecţilor participanţi în acest studiu este mic, trebuie considerat faptul că în activitatea normală a unei clinici, specialistul trebuie să poată să-şi formeze un plan terapeutic plecând de la rezultatele individuale şi uneori contradictorii obţinute în urma testărilor. Rezultatele prezentate indică o îmbunătăţire a echilibrului pentru subiectul nr. 2 comparativ cu subiectul nr. 1. Pe baza datelor din literatura medicală putem considera că în cazul subiectului nr. 1 este indicată prescripţia unui dispozitiv medical încălţăminte terapeutică sau orteze pentru picior cu rolul de a îmbunătăţi echilibrului în special prin 
lateral sway. Thus, in order to reduce the ellipse area containing $95 \%$ of the data it is indicated to increase the support area by using a lateral flare, while to reduce medio-lateral sway, a customized foot orthose made of rigid materials can be used. Also, the presented data can be of great use to evaluate the recovery program, given that in order to control movement in frontal and sagittal planes, different muscle groups are involved.

Diminishing balance immediately after surgery is consistent with the results of the study conducted by Gstoettner [19], patients not being subjected to a protocol of proprioception education before surgery. In addition to decreased proprioception in the postoperative period, another possible cause of reduced stability is the low muscle tone and strength. If patients are not subjected to the protocol of proprioception education in the preoperative period, the only way to increase the stability is by exercising muscle groups, which can be done by using orthoses.

\section{CONCLUSIONS}

A correct posture is a prerequisite for the effective functioning of the human body. Stabilometry is a method for assessing static posture. In stabilometric assessments, the force platform is a tool offering a multitude of parameters which can be correlated with both the risk of falls, maintaining a correct posture, the effort required to maintain balance and the design parameters of medical devices.

Efforts to standardize elements of stabilometric procedures have led to establishing broad principles but the results cannot be said to represent a consensus of experts. The best example is that of foot position, for which this paper presented no less than 4 variants. This makes it difficult to compare the results of different works and therefore increased attention should be paid to specifying the procedures used.

In this work we studied the evolution of a representative selection of stabilometric parameters by analyzing two subjects who underwent surgery for total knee arthroplasty. Assessments were made preoperatively, postoperatively and after a recovery reducerea balansului medio-lateral. Astfel, pentru reducerea ariei elipsei conţinând 95\% dintre date este indicată creşterea bazei de sprijin prin utilizarea unei tălpi cu suprafaţa mărită (lateral flare), în timp ce pentru reducerea balansului mediolateral poate $\mathrm{fi}$ utilizată o orteză pentru picior individualizată, construită din materiale rigide. De asemenea, datele prezente pot fi de un real folos evaluării programului de recuperare, dat fiind faptul că, pentru controlul mişcării în plan frontal şi sagital sunt implicate grupe musculare diferite.

Diminuarea echilibrului imediat postoperator este în concordanţă cu rezultatele studiului efectuat de Gstoettner [19], pacienţii nefiind supuşi unui protocol de educare a propriocepţiei în preoperator. Pe lângă scăderea propriocepţiei în perioada postoperatorie, o altă cauză posibilă a scăderii stabilităţii este reprezentată de scăderea tonusului şi forţei musculare. Dacă pacienţii nu sunt supuşi protocolului de educare a propriocepţiei în perioada preoperatorie, singura posibilitate de creştere a stabilităţii este reprezentată de educarea grupelor musculare, ceea ce se poate realiza prin utilizarea ortezelor.

\section{CONCLUZII}

O postură corectă reprezintă o condiţie esenţială pentru o funcţionare eficientă a corpului uman. Stabilometria reprezintă o metodă de evaluare statică a posturii. În cadrul evaluărilor stabilometrice, platforma de forţă reprezintă un instrument care oferă o multitudine de parametri ce pot fi corelaţi atât cu riscul de cădere, performanţa menţinerii unei posturi corecte, efortul necesar menţinerii echilibrului, cât şi cu parametrii constructivi ai dispozitivelor medicale.

Eforturile de standardizare a elementelor procedurilor stabilometrice au dus la enunţarea unor principii generale, dar nu se poate afirma faptul că rezultatele obţinute reprezintă un consens al specialiştilor. Cel mai elocvent exemplu este cel al poziţiei picioarelor, pentru care în această lucrare s-au prezentat nu mai puţin de 4 variante. Acest fapt face dificilă comparaţia între rezultatele diferitelor lucrări şi, de aceea, o atenţie sporită trebuie acordată precizării procedurilor folosite.

În cadrul acestei lucrări s-a studiat evoluţia unei selecţii a parametrilor stabilometrici reprezentativi, fiind analizaţi 2 subiecţi care au trecut printr-o intervenţie chirurgicală de artroplastie a genunchiului. Evaluările au fost făcute preoperator, postoperator şi 
period of approximately one month. The main parameters analyzed (COP displacement, average speed of COP and ellipse area of 95\%) are cited in the literature as a reflection of general postural control and are correlated with the technical parameters for the design of medical devices having an active role in maintaining balance.

The results reveal the existence of a different behaviour in subjects after surgery. The formulation of a general conclusion is impossible in this situation. However, in clinical terms, the specialist should be aware of the subjective response of each patient and should base treatment prescription on both clinical tests based on medical evidence and on the individual response of the subject in the procedure used.

The stabilometric assessment procedure to provide technical parameters for design of medical devices used in the conservative treatment of the foot is dependent on the objective of stabilometric assessment and must contain the following elements:

- number of experimental sessions (e.g. reference after conservative intervention after a period of medical recovery);

- conditions: eyes closed (EC) and eyes open (EO). The order of measurements is: open eyes followed by closed eyes;

- measurement time;

- number of tests for each condition;

- foot position;

- position of the body/arms;

- recording frequency;

- signal filtering frequency;

- a favourable environment for conducting stabilometric measurements (level of noise, distracting elements etc.).

This procedure is applicable regardless of the type of intervention: surgery or conservative intervention (based on medical device). In Romania the medical device design specialist is not involved in the interdisciplinary team assessing patients pre- and postintervention. This paper shows the importance of including such a specialist because, in the case of subject no. 1 , the existence of a bilateral flat foot and a după o perioadă de recuperare de aproximativ 1 lună. Principalii parametri analizaţi (deplasarea COP, viteza medie a COP şi aria elipsei 95\%) sunt citaţi în literatura de specialitate ca fiind o reflectare a performanţei controlului postural general şi sunt corelaţi cu parametrii tehnici de proiectare a dispozitivelor medicale cu rol activ în menţinerea echilibrului.

Rezultatele obţinute au evidenţiat existenţa unui comportament subiectiv diferit în urma intervenţiei chirurgicale. Formularea unor concluzii generale este imposibilă în această situaţie. Totuşi, din punct de vedere clinic, specialistul trebuie să fie conştient de răspunsul subiectiv al fiecărui pacient şi să-şi bazeze prescripţia tratamentului atât pe studiile clinice bazate pe dovezile medicale, cât şi pe răspunsul individual al subiectului în cadrul procedurii folosite.

Procedura de evaluare stabilometrică pentru furnizarea unor parametri tehnici de proiectare a dispozitivelor medicale destinate tratamentului conservativ al piciorului este dependentă de obiectivul evaluării stabilometrice şi trebuie să conţină următoarele elemente:

- numărul de sesiuni experimentale (spre exemplu, referinţa, după intervenţia conservativă, după o perioadă de recuperare medicală);

- condiţii: ochi închişi (EC) şi ochi deschişi (EO). Ordinea de efectuare a măsurătorilor este: ochi deschişi urmată de ochi închişi;

- timpul de măsurare;

- numărul de probe pentru fiecare condiţie;

- poziţia picioarelor;

- poziţia corpului/braţelor;

- frecvenţa de înregistrare;

- frecvenţa de filtrare a semnalului;

- un ambient propice pentru efectuarea măsurătorilor stabilometrice (nivel de zgomot, elemente ce pot distrage atenţia etc.).

Această procedură este aplicabilă indiferent de tipul intervenţiei: intervenţie chirurgicală sau intervenţie conservativă (bazată pe dispozitiv medical). În România nu există o practică curentă în includerea specialistului în proiectarea dispozitivelor medicale în echipa interdisciplinară de evaluare pre şi post intervenţie a pacienţilor. Lucrarea de faţă arată importanţa includerii unui astfel de specialist, deoarece, în cazul subiectului nr. 1, existenţa unui picior plat bilateral şi a unui halux valgus pronunţat unilateral 
pronounced unilateral hallux valgus negatively influences gait biomechanics. Medical evidence shows that medical devices are useful or recommended in such situations. For these reasons we believe that a medical device - therapeutic shoes - is an integral part of the rehabilitation program. influenţează biomecanica mersului într-un mod negativ. Dovezile medicale demonstrează faptul că dispozitivele medicale sunt utile sau indicate în astfel de situaţii. Din aceste motive considerăm că un dispozitiv medical - încălţăminte terapeutică - reprezintă o parte integrantă a programului de recuperare.

\section{REFERENCES}

1. Nigg, B., Hintzen, S., Ferber, R., Effect of an unstable shoe construction on lower extremity gait characteristics, Clin Biomech, 2006, 21, 1, 82-88.

2. Goryachev, Y. et al., The effect of manipulation of the center of pressure of the foot during gait on the activation patterns of the lower limb musculature, J Electromyogr Kines, 2011, 21, 333-339.

3. Liebenson, C., Sensory-Motor Training, Part I, Dynamic Chiropractic, 2001, 19, 09.

4. Barrett, D.S., Cobb, A.G., Bentley, G., Joint proprioception in normal, osteoarthritic and replaced knees, J Bone Joint Surg $B r, 1991,73,53-56$.

5. Shimizu, M., Andrew, P., Effect of heel height on the foot in unilateral standing, J Phys Ther Sci, 1999, 11, 95-100.

6. Melzer, I., Benjuya, N., Kaplanskip, J., Postural stability in the elderly a comparison between fallers and non-fallers, Age Ageing, 2004, 33, 602-607.

7. Jonsson, E., Seiger, A., Hirschfeld, H., One-leg stance in healthy young and elderly adults a measure of postural steadiness, Clin Biomech, 2004, 19, 688-694.

8. Duarte, M., Freitas, S.M., Revision of posturography based on force plate for balance evaluation, Rev Bras Fisioter, São Carlos, 2010, 14, 3, 183-92.

9. Siqueira, C.M. et al., Misalignment of the knees: Does it affect human stance stability, J Bodyw Mov Ther, 2011, 15, 235-241.

10. Ruhe, A., Fejer, R., Walker, B., The test-retest reliability of centre of pressure measures in bipedal static task condition A systematic review of the literature, Gait Posture, 2010, 32, 436-445.

11. Yasuda, T., Nakagawa, T., Inoue, H., Iwamoto, M., The role of the labyrinth, proprioception and plantar mechanosensors in the maintenance of an upright posture, Eur Arch Otorhinolaryngol, 1999, 256, S27-32.

12. Chiari, L. et al., Stabilometric parameters are affected by anthropometry and foot placement, Clin Biomech, 2002, 17, 666-677.

13. Hatton, A.L., Rome, K., Postural Stability Measurement Implications for Footwear Interventions, in Ravindra S. Goonetilleke (Ed.), The science of footwear, 2012, 513-534, Boca Raton, FL, United States: CRC Press.

14. Borg, F., Herrala, M., The Pilot Stabilometric System, Biosignals Project, Jyväskylä University, Chydenius Institute, Version 3/16/04, 2004.

15. Pinsault, N., Vuillerme, N., Test-retest reliability of centre of foot pressure measures to assess postural control during unperturbed stance, Med Eng Phys, 2009, 31, 276-286.

16. Baratto, L. et al., A new look at posturographic analysis in the clinical context sway density vs. other parametrization techniques, Motor Control, 2002, 6, 246-270.

17. Rome, K., Brown, C.L., Randomized clinical trial into the impact of rigid foot orthoses on balance parameters in excessively pronated feet, Clin Rehabil, 2004, 18, 624. 
18. Menz, H.B., Lord, S.R., Footwear and Postural Stability in Older People, J Am Podiatr Med Assoc, 1999, 89, 7.

19. Gstoettner, M., Raschner, C., Dirnberger, E., Leimser, H., Krismer, M., Preoperative proprioceptive training in patients with total knee arthroplasty, The Knee, 2011, 18, 265-270. 